\title{
RNAi Targeting Embryonic Myosin Heavy Chain Isoform Inhibited Bound Thrombin-Induced Migration of Vascular Smooth Muscle Cells
}

\author{
Masanori Sunagawa Seiji Shimada Mariko Nakamura Tadayoshi Kosugi \\ 1st Department of Physiology, Unit of Physiological Science, School of Medicine, University of the Ryukyus, \\ Nishihara, Japan
}

\section{Key Words}

Bound thrombin $\cdot$ SMemb gene $\cdot$ siRNA $\cdot$ Cultured vascular smooth muscle cells $\cdot$ Migration tion activity by $1.28 \pm 0.15$-fold $(p<0.05)$. Thus, SMemb plays an important role in bound thrombin-induced cell migration activity of cultured vascular smooth muscle cells.

Copyright $\odot 2008$ S. Karger AG, Basel

\section{Introduction}

The proliferation of vascular smooth muscle (VSM) cells plays a major role in vascular restenosis following coronary interventions [1-3]. The highly proliferative VSM cells consist of synthetic type, which can produce growth factors and extracellular matrices, thereby developing intimal hyperplasia. It was demonstrated that $\mathrm{SMemb}$, an embryonic myosin heavy chain (MHC) isoform, was highly expressed in synthetic cell type, while other MHC isoforms (SM1 and SM2) were expressed in contractile type [4]. Therefore, a switch of MHC isoform expression seemed to closely link to proliferation and $\mathrm{mi}-$ gration of VSM cells.

It was demonstrated by in vitro study that thrombin activity in the presence of fibrin clot was not inhibited by heparin. Francis et al. [5] revealed that the activity of thrombin remained in the clot. The residual thrombin in clot has been called postclotting thrombin (bound thrombin). After percutaneous transluminal coronary angioplasty, levels of fibrinopeptide A, thrombin-antithrombin III complex and prothrombin fragments $1+2$ were

\section{KARGER}

Fax +4161306 1234 E-Mail karger@karger.ch www.karger.com

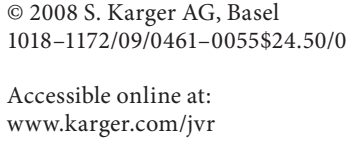

Dr. Masanori Sunagawa

1st Department of Physiology, Unit of Physiological Science

School of Medicine, University of the Ryukyus

207 Uehara, Nishihara, Okinawa 903-0215 (Japan)

Tel. +81 98895 1108, Fax +81 98895 1402, E-Mail sunagam@med.u-ryukyu.ac.jp 
significantly increased in many patients, indicating coronary thrombosis by procoagulant activity $[6,7]$. It was reported that the coronary thrombosis by procoagulant activity was resistant to the treatment by high doses of heparin $[8,9]$. In vitro studies demonstrated that thrombus-associated thrombin and factor Xa were resistant to heparin treatment $[10,11]$. Therefore, heparin-resistant procoagulant activity might be caused by bound thrombin. In addition, coagulation factors including thrombin and tissue factor are involved in the development of vascular restenosis after interventional treatment $[12,13]$. We hypothesized that bound thrombin in the thrombus plays an important role in the development of restenosis.

We have reported some unique biological and physicochemical characteristics of bound thrombin [14-16], including platelet aggregation, complex with fibrin fragments. We also demonstrated that bound thrombin enhanced the phenotype conversion of VSM cells towards a synthetic type by upregulating mRNA expressions of SMemb and plasminogen activator inhibitor type 1 (PAI1) by the comparative reverse transcription polymerase chain reaction (RT-PCR) method [17]. Therefore, bound thrombin might contribute to the pathogenesis of restenosis after vascular injury. We also clarified the role of SMemb gene expression in phenotypic change in cultured rabbit VSM cells using siRNA-targeting SMemb mRNA. Consequently, it was demonstrated by the comparative RT-PCR method that PAI- 1 and $\beta$-actin mRNA expressions were downregulated in the treated cells with SMemb siRNA, indicating the inhibition of phenotypic change toward the synthetic type by the knockdown of SMemb gene expression [18].

We constructed siRNA expression plasmid vector-targeting SMemb mRNA. In order to more accurately test whether the bound thrombin-induced upregulation of SMemb and PAI-1 mRNA could be inhibited by the SMemb-specific siRNA expression vectors, the expression of mRNAs was measured by Northern blot analysis in this study. We also tested whether the SMemb-specific siRNA expression vector inhibited bound thrombin-induced changes in cell proliferation and migration activities.

\section{Materials and Methods}

Animals, Animal Care and Cell Culture

All animals were cared for according to the Guidelines for Animal Experiments in Research Institutes (Notice No. 71 of the Ministry of Education, Culture, Sports, Science and Technology,
2006) and the Guidelines for Animal Experiments issued by the University of the Ryukyus. VSM tissues were isolated and cultured as previously reported [19]. In brief, thoracic aorta was excised from male Japanese white rabbits weighing $2.5 \mathrm{~kg}$ (Kyudo Co., Kumamoto, Japan) and cut into small pieces (about $4 \times$ $4 \mathrm{~mm}$ ) after the endothelium was mechanically removed. The tissues were plated on cell culture dishes with the luminal side down, and cultured under $5 \% \mathrm{CO}_{2}$ at $37^{\circ} \mathrm{C}$ in Dulbecco's modified Eagle's medium (DMEM) containing $10 \%$ fetal bovine serum (FBS) plus penicillin and streptomycin. The 6th passage of the cultured VSM cells was employed for the experiments.

\section{Preparation of Bound Thrombin}

Preparation of bound thrombin was carried out as previously described $[15,20]$. In brief, a mixture of $0.5 \mathrm{ml}$ of bovine $\alpha$-thrombin $(500 \mathrm{U} / \mathrm{ml})$ and $2.5 \mathrm{ml}$ of rabbit fibrinogen $(1.5 \mathrm{mg} / \mathrm{ml}$ in serum-free DMEM) was incubated for $15 \mathrm{~min}$ at $37^{\circ} \mathrm{C}$ to allow a clot to form. After removal of the supernatant, the clot was rinsed twice with $2 \mathrm{ml}$ of serum-free DMEM. The clot was then crushed mechanically using a glass rod (approx. 500 strokes). The insoluble materials were removed by centrifugation at 3,000 rpm for 15 min at $4{ }^{\circ} \mathrm{C}$. The clotting activity of the bound thrombin was measured by BBL ${ }^{\mathrm{TM}}$ FibroSystem ${ }^{\circledR}$ (Becton Dickinson, Cockeysville, Md., USA). The prepared bound thrombin was further diluted with $10 \%$ FBS in DMEM to a final concentration of $10 \mathrm{U} / \mathrm{ml}$. For comparison, purified rabbit fibrinogen $(10 \mu \mathrm{g} / \mathrm{ml})$ and bovine $\alpha$ thrombin $(10 \mathrm{U} / \mathrm{ml})$ were used.

\section{Construction of Plasmid Vectors for Expression of SMemb} mRNA-Specific siRNAs

To search candidates for siRNA-targeting nucleotide sequences which have 21 nucleotides, start with double adenine and have guanine/cytosine contents from 40 to $50 \%$, we used an siRNA insert design on-line tool provided on the homepage of Ambion Inc. (Austin, Tex., USA). Consequently, 3 target sites of rabbit SMemb mRNA (DDBJ accession No. D10280) were chosen: $5^{\prime}$-aaggaccttgaagcgcaaatc-3' 454-474 (ORF-1), 5'-aacaaggatctgaaggccaag-3' 955-975 (ORF-2) and 5'-aaccgtgtcttaagactctgc-3' 1630-1650 ( $3^{\prime}$ UTR). These sequences did not have any homology to other MHC isoforms and any mammalian cDNA sequences based on the BLAST search. After the sense and antisense hairpin siRNA templates were annealed, the siRNA expression vectors were constructed using pSilencer ${ }^{\mathrm{TM}}$ 2.1-U6 neo (Ambion) according to the manufacturer's procedures. The 3 kinds of annealed template were ligated into pSilencer, which were digested with BamHI and HindIII.

Transfection of SMemb-siRNA Expression Vector into Cultured VSM Cells

The constructed siRNAs were introduced intracellularly into the cultured VSM cells with Lipofectamine ${ }^{\mathrm{TM}}$ and Plus ${ }^{\mathrm{TM}}$ reagents (Invitrogen, Carlsbad, Calif., USA) according to the manufacturer's procedures. First, precomplex of each SMemb/pSilencer with $30 \mu \mathrm{g}$ Plus reagent in $200 \mu \mathrm{l}$ OPTI-MEM ${ }^{\circledR}$ medium (Invitrogen) was prepared, and then incubated for $15 \mathrm{~min}$ at room temperature. Following this, $20 \mu \mathrm{g}$ Lipofectamine reagent was diluted with $200 \mu \mathrm{l}$ OPTI-MEM. To form the siRNA-Plus-Lipofectamine reagent complexes, $200 \mu \mathrm{l}$ of precomplexed siRNA and $200 \mu \mathrm{l}$ of the diluted Lipofectamine reagent were combined and incubated for $30 \mathrm{~min}$ at room temperature. After that, the $400 \mu \mathrm{l}$ of com- 
plexes was diluted into $1.6 \mathrm{ml}$ of OPTI-MEM and added to the VSM cells in $25-\mathrm{mm}^{2}$ culture flasks (Becton Dickinson). VSM cells were incubated for the first $4 \mathrm{~h}$ at $37^{\circ} \mathrm{C}$, and then $2 \mathrm{ml}$ of DMEM containing 10\% FBS was added and incubated for another $44 \mathrm{~h}$. We tested if cell viability was affected by transfection after $48 \mathrm{~h}$. Cell viability was evaluated as the relative number of cells to nontreatment (without Lipofectamine and pSilencer expression vector). Consequently, cell viability was neither changed by treatment with Lipofectamine nor by pSilencer expression vector: nontreatment, $0.53 \pm 0.018$; Lipofectamine alone, $0.49 \pm 0.015$ $(-) / p$ Silencer $(1 \mu \mathrm{g} / \mathrm{ml}), 0.52 \pm 0.041 ;(-) / \mathrm{pSilencer}(3 \mu \mathrm{g} / \mathrm{ml}), 0.52$ \pm 0.038 .

\section{Northern Blot Analysis}

To measure the expression of MHC isoform mRNAs, we performed Northern blot analysis. Total RNA was extracted from approximately $8 \times 10^{5}$ cultured VSM cells using a PURESCRIPT ${ }^{\circledR}$ RNA Isolation Kit cell and tissue kit (GentraSystem, Minneapolis, Minn., USA). For Northern blotting, each of $10 \mu \mathrm{g}$ RNAs was denatured and loaded on a $1.1 \%$ agarose-formaldehyde gel. Subsequently, RNAs were transferred onto a positively charged nylon membrane (Roche Diagnostics GmbH, Mannheim, Germany), and UV cross-linked with a HybriLinker HL-2000 (UVP Inc., Upland, Calif., USA). The templates of cDNA probes for SMemb, PAI-1 and glyceraldehydes-3-phosphate dehydrogenase (GAPDH), which was used as an internal control, were prepared by RT-PCR as previously described [18]. The cDNA probe was labeled with $\left[\alpha^{-32} \mathrm{P}\right]$ dCTP using a Rediprime ${ }^{\mathrm{TM}}$ II random prime labeling system (Amersham Biosciences, Little Chalfont, UK), and hybridized with ExpressionHyb solution (BD Biosciences Clontech, Palo Alto, Calif., USA) at $68^{\circ} \mathrm{C}$ for $1 \mathrm{~h}$. The membrane was washed with $2 \times$ SSC, $0.05 \%$ SDS solution for $20 \mathrm{~min}$ at room temperature twice; this was followed by a $0.1 \times$ SSC, $0.1 \%$ SDS solution with continuous shaking at $50^{\circ} \mathrm{C}$ for 20 min twice. The radioactivity on the membrane was measured by Fuji imaging plate type BAS-IIIs (Fuji Film, Kanagawa, Japan) using Fuji film BAS-1500. The intensities of the bands were measured by $\mathrm{NIH}$ Image ${ }^{\circledR}$.

\section{Comparative RT-PCR}

To measure the expression of SM1 and SM2 mRNAs, we performed comparative RT-PCR as previously reported [17, 19]. The primers for MHC isoforms (SM1 and SM2) and GAPDH were used as previously described [17]. The PCR products were separated on $2.5 \%$ agarose gel containing ethidium bromide with a half concentration of Tris-borate-EDTA electrophoresis buffers ( $\mathrm{pH}$ 7.5). The fluorescent intensities of amplified cDNA bands were estimated by NIH Image.

\section{Immunofluorescence Staining of Cultured VSM Cells}

For immunofluorescence, we employed mouse anti-rabbit SMemb monoclonal antibody (Yamasa Corp., Chiba, Japan) according to the method given in the previous report [21]. Fortyeight hours after introduction, the cultured rabbit VSM cells were fixed with $10 \%$ formalin neutral buffer solution (Wako, Osaka, Japan) for $40 \mathrm{~min}$ at room temperature. The fixed VSM cells were treated with $0.2 \%$ Triton X-100 in PBS for 5 min to increase their membrane permeability. The cells were incubated with $3 \%$ nonfat milk in PBS for $1 \mathrm{~h}$ at room temperature, and then the cells were incubated for $1 \mathrm{~h}$ with mouse anti-rabbit SMemb antibody, which was diluted to $1: 3,000$ by $3 \%$ nonfat milk in PBS. After washing 4 times with $0.05 \%$ Tween 20 in PBS for 10 min each, the cells were incubated for $1 \mathrm{~h}$ with 1:3,000 diluted tetramethylrhodamine isothiocyanate (TRITC)-conjugated goat anti-mouse IgG. Cell nuclei were counterstained with 4',6-diaminidin-2-phenylindoldihydrochloride (DAPI). The cell images were analyzed using a Nikon ECLIPSE E600 microscope (Nikon, Tokyo, Japan) with the $\mathrm{B}-2 \mathrm{E} / \mathrm{C}$ fluorescence filter for FITC staining and the UV-2E/C fluorescence filter for DAPI staining.

\section{Western Blot Analysis}

Crude myosin extracts were prepared after 48-hour treatment according to the method by Rovner et al. [22] with a minor modification. To measure the protein level of SMemb after treatment of the cultured VSM cells with ORF-2/pSilencer, Western blots were performed as previously reported [17]. To separate the proteins in the crude myosin extracts, SDS-PAGE with a 4-10\% gradient gel was performed using a PhastSystem (GE Healthcare UK Ltd., Chalfont St Giles, UK). The proteins in the gel were electrically blotted onto polyvinylidene difluoride membrane (Immune-Blot PVDF Membrane; Bio-Rad Laboratories, Hercules, Calif., USA) at $4^{\circ} \mathrm{C}, 1.5 \mathrm{~mA} / \mathrm{cm}^{2}$ for $2 \mathrm{~h}$. After blotting, the membrane was blocked with $3 \%$ nonfat milk in PBS for $2 \mathrm{~h}$ at room temperature, and then the membrane was incubated at $4^{\circ} \mathrm{C}$ overnight with a monoclonal antibody against SMemb (Yamasa Corp.), which was diluted to $1: 1,000$ by $3 \%$ nonfat milk in PBS. After 5 times washing with $0.1 \%$ Tween 20 in PBS (PBST) for $10 \mathrm{~min}$ each, the membrane was incubated with 1:3,000 diluted horseradish peroxidase-conjugated sheep anti-mouse IgG $\mathrm{Ig}_{2 \mathrm{~b}}$ (The Binding Site, Birmingham, UK) in $1 \%$ nonfat milk in PBST at room temperature for $1 \mathrm{~h}$. After washing 4 times by PBST and 2 times by PBS, immune complex was visualized using ECL Plus Western blotting detection reagents (GE Healthcare). The signal intensities of SMemb protein bands were analyzed by NIH Image.

\section{Cell Proliferation and Migration Assay}

Cell proliferation assay of the cultured VSM cells was examined by the cell proliferation reagent WST-1 or the cell proliferation ELISA 5-bromo-2'-deoxyuridine (BrdU, colorimetric; Roche Diagnostics). Ten microliters of the cell proliferation reagent WST-1 or BrdU labeling solution was added to each well. After 1hour incubation of the cells with the WST-1 reagent, the absorbance at $415 \mathrm{~nm}$ (reference wavelength of $550 \mathrm{~nm}$ ) was measured by an MTP-300 microplate reader (Corona Electric, Ibaragi, Japan). To examine the effects of pSilencer vectors on bound thrombin-induced cell proliferation, the cells were cultured for $48 \mathrm{~h}$ in the absence (PBS) or presence of bound $\alpha$-thrombin $(10 \mathrm{U} / \mathrm{ml})$. After that, the cultured cells were trypsinized, and then $3.0 \times 10^{3}$ cells (in $100 \mu \mathrm{l}$ of $10 \%$ FBS-DMEM) were plated into each well of a 96-well microplate (Corning Co., Corning, N.Y., USA) and incubated for another $48 \mathrm{~h}$ with the vectors $[(-) / \mathrm{pSilencer}$, GAPDH/ pSilencer and ORF-2/pSilencer] at a concentration of $1 \mu \mathrm{g} / \mathrm{ml}$. Cell proliferation was evaluated by $n$-fold increase in the number of viable cells before and after 48-hour treatment with the vectors. The blank value was the absorbance of the culture medium without cells. The absorbance was converted to cell numbers based on comparisons with known numbers of cultured cells. For the determination of DNA synthesis, BrdU incorporation was added at $72 \mathrm{~h}$ after seeding the cells ( $24 \mathrm{~h}$ prior to completion of treatment with ORF-2/pSilencer) and quantitated at $24 \mathrm{~h}$ after addition of 
Fig. 1. Expression of SMemb mRNA in the cells after treatment with ORF-2/pSilencer. a Northern blot analysis of SMemb and GAPDH mRNA expressions after 48-hour treatment with different concentrations of ORF-2/pSilencer (0-1 $\mu \mathrm{g} / \mathrm{ml})$. b Bar graph showing the summary data of $\mathbf{a}$. Data represent relative mean values $\pm \mathrm{SE}$ of the ratio of SMemb/GAPDH mRNA from 7 different experiments. ${ }^{*} \mathrm{p}<0.05$ when compared with $0 \mu \mathrm{g} / \mathrm{ml}$ (lipofectamine alone). c Comparative RT-PCR study on the offtarget effects of ORF-2/pSilencer $(0-1 \mu \mathrm{g} /$ $\mathrm{ml}$ ) on SM1 and SM2 mRNA expressions. Data represent relative mean values $\pm \mathrm{SE}$ of ratios of SM1 or SM2/GAPDH mRNA from 8 different experiments.

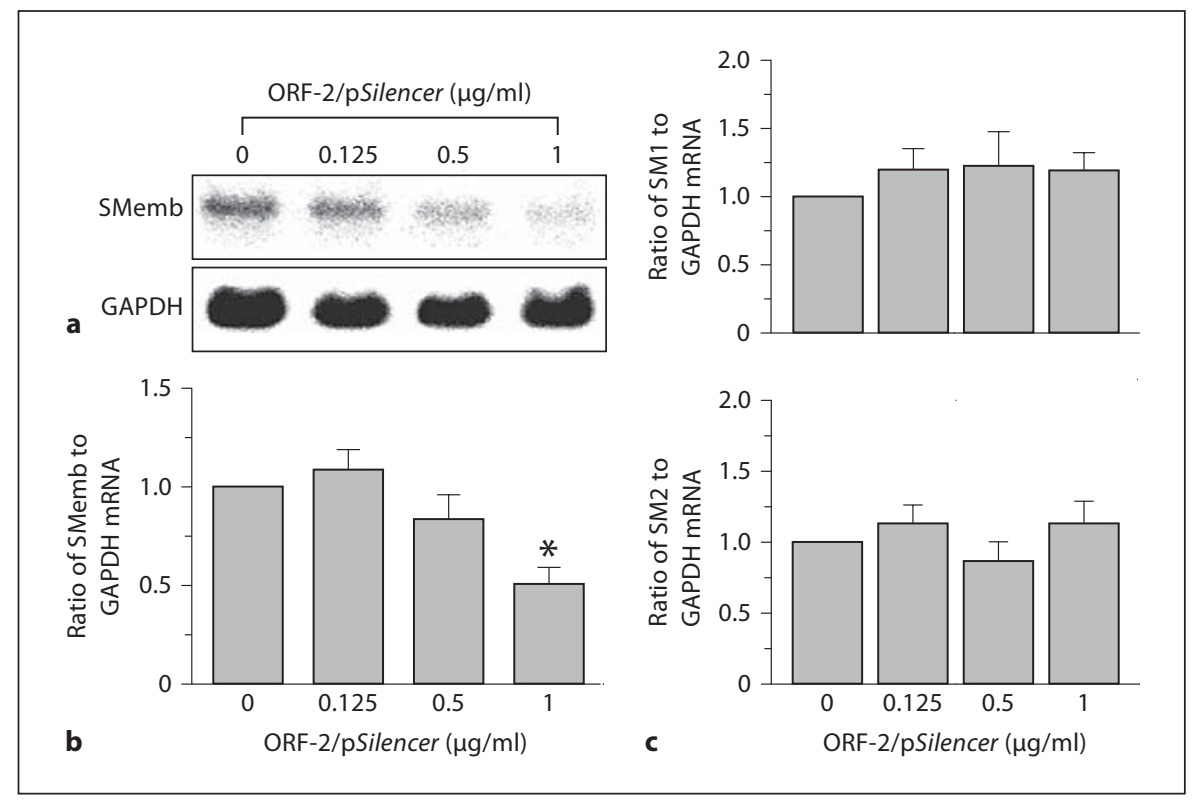

the BrdU solution. The cells were denatured and fixed by incubation for 30 min with the FixDenat solution (Roche Diagnostics). For detection of the incorporated BrdU, the cells were incubated for $2 \mathrm{~h}$ with a peroxidase-conjugated anti-BrdU antibody (1:100 dilutions). After 3 washes by PBS, a substrate (tetramethylbenzidine) was added to each well, and then the absorbance at $370 \mathrm{~nm}$ (reference at $492 \mathrm{~nm}$ ) was measured after $10 \mathrm{~min}$ of incubation.

For migration assay, $1.0 \times 10^{4}$ cells of the cultured VSM cells were seeded onto the $8-\mu \mathrm{m}$ FALCON ${ }^{\circledR}$ HTS FluoroBlok ${ }^{\circledR}$ Inserts (Becton Dickinson), which were precoated with type I collagen from rat tail. In the lower wells of each 24 -well plate, $500 \mu \mathrm{l}$ of $10 \%$ FBS-DMEM were added. After incubation for $23 \mathrm{~h}$ at $37^{\circ} \mathrm{C}$, the fluorescent dye calcein-AM (Dojindo, Kumamoto, Japan) was added to each insert at a final concentration of $2 \mu \mathrm{g} / \mathrm{ml}$, and the cells were further incubated for another $1 \mathrm{~h}$ to label them. The VSM cells on the inserts were fixed by $10 \%$ formalin-PBS. The membranes were removed and mounted on glass slides with coverslips. The VSM cells that had migrated to the lower side of the membrane were counted under the microscope (magnification $\times 400$ ) with the B-2E/C fluorescence filter inserted. The migration activity was expressed as the averaged number of migrated cells in 4 different high-power fields (HPF). To test the effect of bound thrombin with or without ORF-2/pSilencer on cell migration activity, the cultured VSM cells (in $25-\mathrm{cm}^{2}$ flasks) were stimulated by bound thrombin for $48 \mathrm{~h}$, followed by treatment with ORF-2/pSilencer for another $48 \mathrm{~h}$. After that, the cells were trypsinized, suspended in 10\% FBS-DMEM, and plated onto the insert at a density of $1.0 \times 10^{4}$ cells/insert for cell migration assay.

Data Analysis

Statistical analysis was performed by either one-way analysis of variance (ANOVA) followed by Bonferroni/Dunn's multiple comparison tests or Student's unpaired t test, using StatView version 4.5 (Abacus Concepts, Berkeley, Calif., USA). p $<0.05$ was defined as statistical significance.

\section{Results}

To select which of the 3 SMemb-siRNA/pSilencer exert the most effective inhibition of SMemb mRNA expression, $0.5 \mu \mathrm{g} / \mathrm{ml}$ of the 3 kinds of SMemb-siRNA/pSilencer (ORF-1, ORF-2 and 3' UTR SMemb/pSilencer) were introduced into the cultured VSM cells. Based on the number of FITC-positive cells, transfection efficiency was about $80 \%$ when the cells were treated with $1 \mu \mathrm{g} / \mathrm{ml}$ of FITC-labeled ORF-2/pSilencer (data not shown). The ORF-2/pSilencer was the most effective in inhibiting the SMemb mRNA (data not shown). ORF-2/pSilencer downregulated SMemb mRNA expression in a dose-dependent manner (fig. 1a). ORF-2/pSilencer significantly reduced SMemb mRNA expression (relative to GAPDH mRNA expression) to $0.24 \pm 0.05$ at the concentration of $1.0 \mu \mathrm{g} / \mathrm{ml}$, compared with $0 \mu \mathrm{g} / \mathrm{ml}(0.46 \pm 0.06, \mathrm{p}<0.01$; fig. 1b). In order to test specificity of ORF-2/pSilencer on downregulation of SMemb, off-target effects of ORF-2/ pSilencer were tested using other MHC isoforms (SM1 and SM2). Comparative RT-PCR was performed to test the effect of ORF-2/pSilencer treatment on the mRNA expressions of SM1 and SM2 after $48 \mathrm{~h}$. Consequently, mRNA expressions of SM1 and SM2 (relative to GAPDH mRNA expression) were not changed by the treatments with various concentrations of ORF-2/pSilencer, compared with $0 \mu \mathrm{g} / \mathrm{ml}$ (lipofectamine alone; fig. 1c).

Western blot analysis was performed to measure the protein level of SMemb after 48-hour treatment with 
ORF-2/pSilencer (fig. 2a). SMemb protein in crude myosin extracts from cultured VSM cells was increased compared with that from rabbit aorta. SMemb protein level was decreased to $43.5 \%$ in the treatment with ORF-2/pSilencer, compared with that with lipofectamine alone (fig. 2a). To further investigate whether the SMembsiRNA/pSilencer inhibits the expression of SMemb protein in individual cells, immunofluorescence study was performed. In figure $2 b$, although the number of nuclei (stained by DAPI) in the treatment with ORF-2/pSilencer was larger than that with lipofectamine, the number of TRITC fluorescence-positive cells was decreased to $41 \%$ by ORF-2/pSilencer at the concentration of $1 \mu \mathrm{g} / \mathrm{ml}$, compared with lipofectamine alone.

The level of SMemb mRNA in total RNA was measured by Northern blot analysis after 48 -hour stimulation of VSM cells by PBS, fibrinogen $(10 \mu \mathrm{g} / \mathrm{ml})$, thrombin $(10 \mathrm{U} / \mathrm{ml})$ and bound thrombin $(10 \mathrm{U} / \mathrm{ml}$; fig. 3a). Bound thrombin significantly increased the SMemb mRNA expression $(1.4 \pm 0.01, \mathrm{p}<0.01 \mathrm{vs.}$ PBS treatment; fig. 3b). SMemb mRNA expression, however, was not increased by treatment with fibrinogen or thrombin. Another VSM phenotype marker, PAI-1 mRNA expression, was also measured. The bound thrombin significantly increased PAI-1 mRNA expression $(2.65 \pm 0.69, \mathrm{p}<0.01$ vs. PBS treatment), whereas no significant increase in PAI-1 mRNA expressions was found when the cells were treated with fibrinogen and thrombin (fig. 3c).

We investigated whether ORF-2/pSilencer could prevent SMemb mRNA expression in bound thrombinstimulated cultured VSM cells. After the VSM cells were grown to confluence, they were stimulated by $10 \mathrm{U} / \mathrm{ml}$ of bound thrombin or treated with PBS (control). After 48hour stimulation by bound thrombin, culture medium was changed, and then ORF-2/pSilencer was introduced into cultured VSM cells. After 48-hour transfection, total RNA was extracted for Northern blot analysis to measure SMemb mRNA expressions, and the cells were fixed by $10 \%$ formalin for immunofluorescence to detect SMemb protein expressions in individual cells.

Northern blot analysis revealed that bound thrombin significantly increased SMemb mRNA expression in (-)/ pSilencer (empty) vector-treated cells $[1.58 \pm 0.28, \mathrm{p}<$ 0.05 vs. PBS and (-)/pSilencer-treated cells; fig. $4 \mathrm{a}$ and b]. In contrast, bound thrombin-induced upregulation of SMemb mRNA expression was abolished in ORF-2/pSilencer vector-treated cells $[0.97 \pm 0.08, \mathrm{p}<0.05 \mathrm{vs}$. bound thrombin and (-)/pSilencer-treated cells; fig. 4a and b]. Furthermore, bound thrombin increased PAI-1mRNA expression in cultured cells treated with $(-) /$ pSilencer by

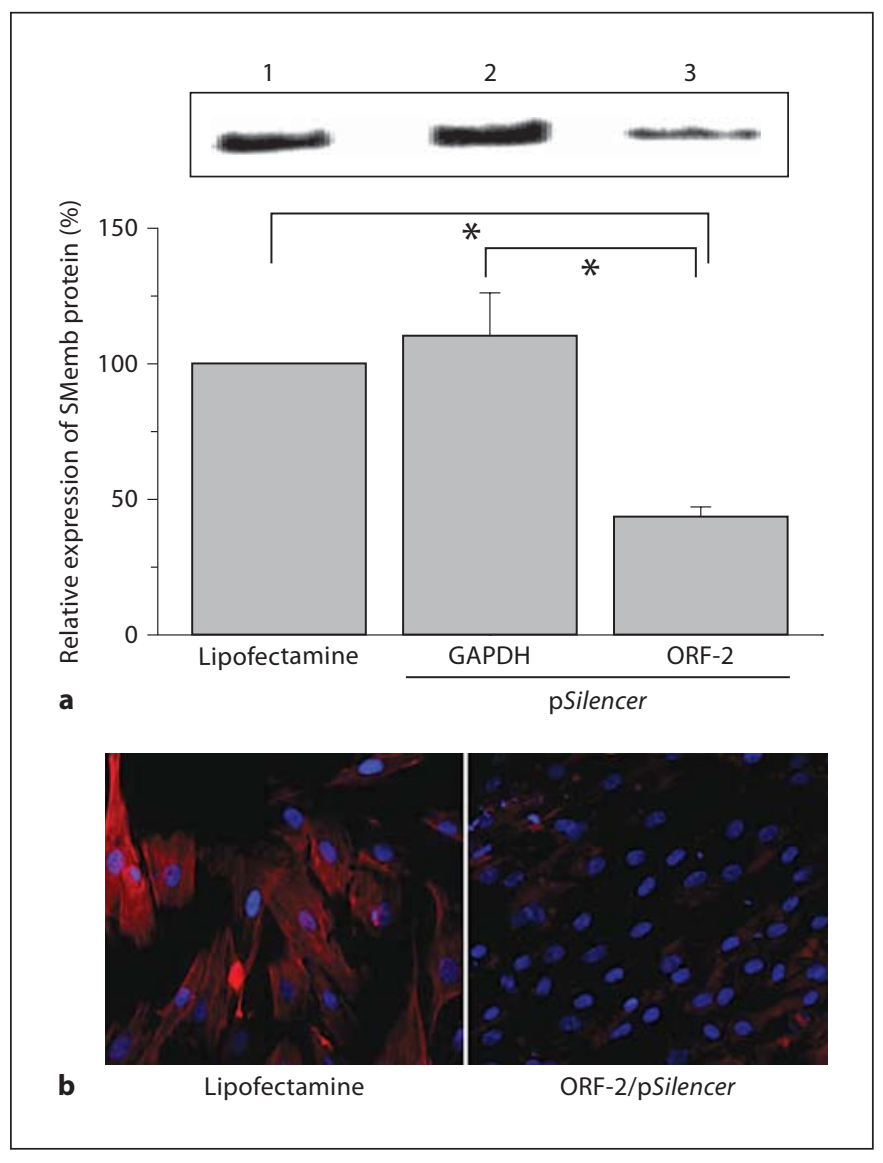

Fig. 2. Expression of SMemb protein in the cells after treatment with ORF-2/pSilencer. a Effect of ORF-2/pSilencer on the SMemb protein expression in cultured VSM cells. Crude myosin extracts prepared from cultured rabbit aortic VSM cells $48 \mathrm{~h}$ after treatment with ORF-2/pSilencer. Lane $1=$ Cultured VSM cells treated with lipofectamine alone; lane $2=\mathrm{GAPDH} / \mathrm{pSilencer}$; lane $3=$ ORF-2/pSilencer. Intensity of the SMemb protein bands was valued by NIH Image and normalized by the value of lipofectamine. Summary data of percentage changes in SMemb protein after 48hour treatment by ORF-2/pSilencer are shown. Data are represented as means \pm SE from 3 separate experiments. ${ }^{*} \mathrm{p}<0.05$, one-way ANOVA followed by post hoc test. b Immunofluorescence staining for SMemb protein expressions. The cells were fixed with $10 \%$ formalin-PBS at $48 \mathrm{~h}$ after treatment, and then immunofluorescence staining for SMemb protein expression was performed (see Materials and Methods). The cells were treated with lipofectamine alone and $1 \mu \mathrm{g} / \mathrm{ml}$ of ORF-2/pSilencer. Fluorescence by TRITC represents SMemb protein expression. Counterstaining for cell nuclei was performed using DAPI.

$1.50 \pm 0.34$, but there was no statistical significance $[\mathrm{p}=$ 0.085 vs. PBS and (-)/pSilencer-treated cells; fig. 4a and c]. ORF-2/pSilencer decreased PAI-1mRNA expression in bound thrombin-stimulated VSM cells (fig. $4 \mathrm{a}$ and c). 


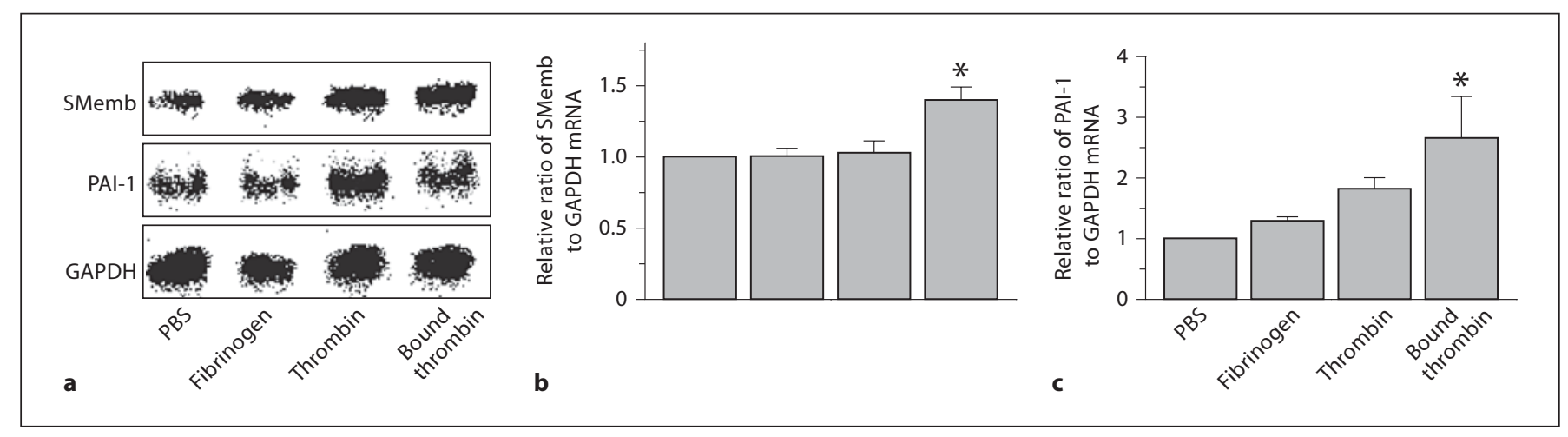

Fig. 3. Effect of bound thrombin on SMemb and PAI-1 mRNA expressions. a Representative Northern blot data on the effect of bound thrombin on the mRNA expressions of SMemb, PAI-1 and GAPDH. PBS, $10 \mu \mathrm{g} / \mathrm{ml}$ of rabbit fibrinogen (fibrinogen) and 10 $\mathrm{U} / \mathrm{ml}$ of bovine $\alpha$-thrombin (thrombin) were used for comparison. b, c Summarized bar graphs showing the effects of bound thrombin on SMemb (b) and PAI-1 (c) mRNA expressions from 4 different experiments each. Ratios of SMemb or PAI-1 to GAPDH mRNA expressions were calculated and expressed as relative ratio to PBS. Data represent means \pm SE $(n=4) .{ }^{*} \mathrm{p}<0.01$ when compared with PBS, one-way ANOVA, followed by Bonferroni/Dunn's multiple comparison test.
Immunofluorescence study revealed that TRITC-fluorescent signals in (-)/pSilencer-treated cells representing SMemb protein expressions were increased by bound thrombin, compared with PBS treatment (intensity in arbitrary units: bound thrombin, $4.5 \pm 7.2$; PBS, $2.1 \pm 4.3$ ). In addition, TRITC-fluorescent signals in ORF-2/pSilencer-treated cells were not increased by bound thrombin (intensity in arbitrary units: bound thrombin, $8.9 \pm$ 11.1; PBS, $8.4 \pm 12.3$ ).

Cell proliferation of cultured VSM cells was evaluated either by increase in the number of viable cells or by DNA synthesis activity measured as the amount of BrdU incorporation. The change in the number of viable cells during 96-hour incubation with bound thrombin (lipofectamine was added to the medium in the latter half of incubation) showed no significant increase: PBS, $1.9 \pm 0.17$-fold; bound thrombin, $1.8 \pm 0.34$-fold (fig. $5 \mathrm{a}$ ). In addition, 48-hour treatment of the cultured cells with (-)/pSilencer, GAPDH/pSilencer or ORF-2/pSilencer had no effect in bound thrombin-stimulated cells (fig. 5a). Although incorporation of BrdU was substantially increased by bound thrombin treatment, there was no statistical significance compared to PBS treatment (fig. 5b). Moreover, (-)/pSilencer, GAPDH/pSilencer and ORF-2/pSilencer had no effect on the incorporation of BrdU by bound thrombin (fig. 5b).

To investigate the role of SMemb in the basal level of cell migration seen without stimulation, the cells were treated for $48 \mathrm{~h}$ with $(-) / \mathrm{pSilencer}$, GAPDH/pSilencer and ORF-2/pSilencer after addition of PBS. Consequent- ly, ORF-2/pSilencer treatment significantly decreased the migration activity to $55.8 \%(6.83 \pm 3.7$ cells/HPF), compared with PBS plus lipofectamine (12.25 \pm 1.5 cells/HPF). Migration activity was significantly increased by about 1.4-fold in the bound thrombin plus lipofectamine group compared to the PBS plus lipofectamine group: PBS, $12.25 \pm 1.5$ cells/HPF; bound thrombin, $17.4 \pm 1.6$ cells/HPF ( $p<0.05$; fig. 6$)$. To investigate the role of SMemb in bound thrombin-stimulated migration, the cells were treated for $48 \mathrm{~h}$ with (-)/ pSilencer, GAPDH/pSilencer and ORF-2/pSilencer after stimulation by bound thrombin. Consequently, ORF-2/ pSilencer treatment significantly reduced the bound thrombin-stimulated migration activity to $69 \%$ compared to (-)/pSilencer treatment: (-)/pSilencer, $17.0 \pm 1.9$ cells/HPF; ORF-2/pSilencer, $11.8 \pm 0.15$ cells/HPF $(\mathrm{p}<$ 0.05; fig. 6).

\section{Discussion}

In the present in vitro study, the knockdown of SMemb gene expression by transfection with ORF-2/pSilencer significantly inhibited bound thrombin-induced migration of cultured rabbit VSM cells. In addition, our data suggest that SMemb plays an important role in cell migration of VSM cells. Although there were many methods to knockdown SMemb gene expression, we employed siRNA expression plasmid vectors because they (1) were resistant to breakdown by RNase, (2) had long-term ex- 


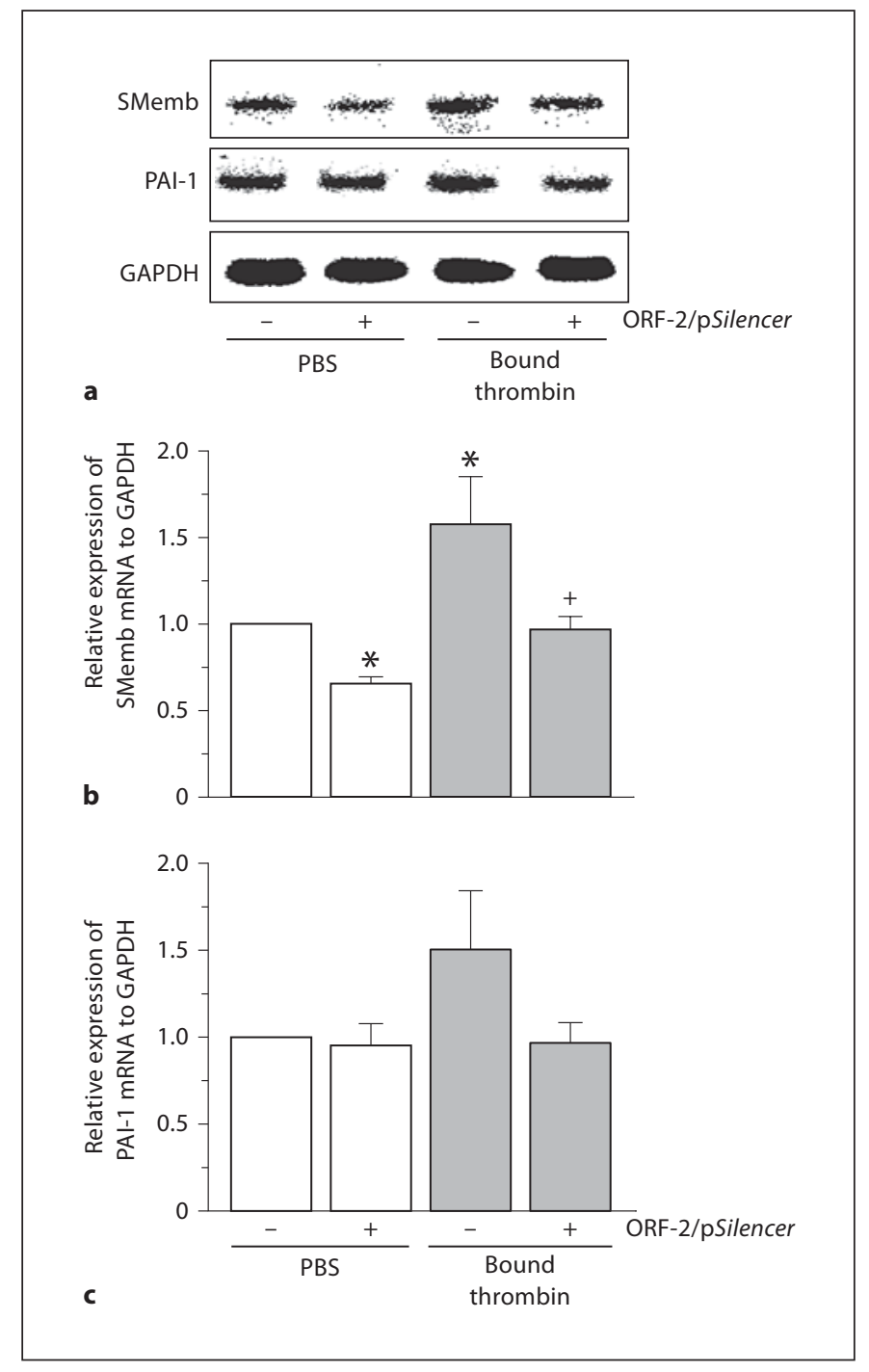

Fig. 4. Effect of ORF-2/pSilencer on bound thrombin-induced upregulation of SMemb mRNA expressions. a Northern blot data on the effect of ORF-2/pSilencer on the mRNA expressions of SMemb, PAI-1 and GAPDH under PBS or bound thrombin-stimulated condition. b, c The cells were treated with $1 \mu \mathrm{g} / \mathrm{ml}$ of either $(-) /$ pSilencer (open bars) or ORF-2/pSilencer (gray bars) for $48 \mathrm{~h}$. Bar graphs summarize the data on the effect of ORF-2/pSilencer on SMemb (b) and PAI-1 (c) mRNA expressions from 4 different experiments each. Ratios of SMemb/GAPDH and PAI-1/GAPDH mRNA expression were calculated and expressed as relative ratio to PBS. ${ }^{*} \mathrm{p}<0.05$ when compared with PBS; ${ }^{+} \mathrm{p}<0.05$ when compared with bound thrombin/empty vector, one-way ANOVA followed by Bonferroni/Dunn's multiple comparison test.

pression in the cells and (3) were applicable to an in vivo study. Since we planned to study whether local delivery of ORF-2/pSilencer by gene-eluting stents prevents balloon denudation-induced vascular restenosis in rabbits,
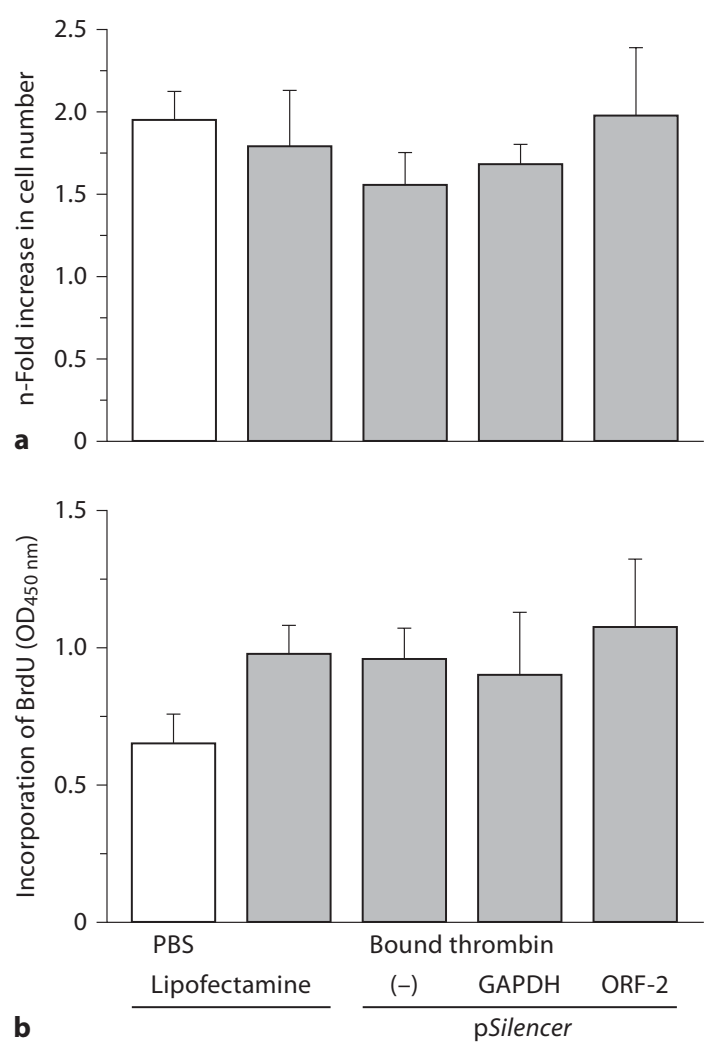

Fig. 5. Cell proliferation assay in ORF-2/pSilencer-treated cultured rabbit VSM cells after stimulation by bound thrombin. a After 48-hour stimulation of cultured VSM cells by PBS (open bars) or bound thrombin (gray bars), the numbers of cells were counted by the WST-1 reagent before and after 48-hour treatments with $1 \mu \mathrm{g} / \mathrm{ml}$ of different plasmid vectors $[(-) / p$ Silencer, GAPDH/pSilencer and ORF-2/pSilencer] or lipofectamine alone. $\mathrm{n}$-Fold increase was calculated by dividing the number of cells after 48-hour treatment with the vectors by that before treatment. Data represent means $\pm \mathrm{SE}(\mathrm{n}=3)$. $\mathbf{b}$ DNA synthesis activity was determined by measuring the incorporation of BrdU into the cells by ELISA. Data represent means $\pm \operatorname{SE}(n=4)$. we took the first step to test the ORF-2/pSilencer plasmid in cultured rabbit VSM cells.

Coagulation factors, including thrombin and tissue factor, are involved in the development of vascular reste- 


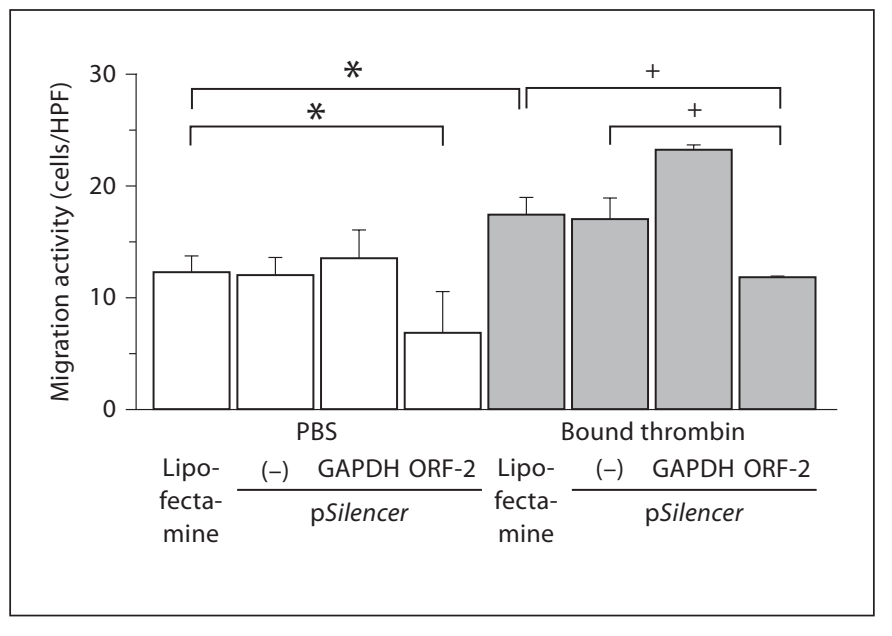

Fig. 6. Cell migration assay in ORF-2/pSilencer-treated cultured rabbit VSM cells after stimulation by bound thrombin. The migration activity is expressed as the averaged number of migrated cells in 4 different HPF. $\times 400$. To test the effect of ORF-2/pSilencer on the basal (PBS, open bars) and bound thrombin-induced (gray bars) cell migration activity, the cultured VSM cells were stimulated by bound thrombin for $48 \mathrm{~h}$, followed by treatment with $1 \mu \mathrm{g} / \mathrm{ml}$ of different plasmid vectors [(-)/pSilencer, GAPDH/ pSilencer and ORF-2/pSilencer] or lipofectamine alone for another $48 \mathrm{~h}$. After that, the cells were trypsinized, suspended in $10 \%$ FBS-DMEM and plated onto the insert at a density of $1.0 \times 10^{4}$ cells/insert for cell migration assay. Data represent means $\pm \mathrm{SE}$ $(\mathrm{n}=4-8) .{ }^{*} \mathrm{p}<0.05$ when compared with PBS plus lipofectamine; ${ }^{+} \mathrm{p}<0.05$ when compared among the groups of the stimulation by bound thrombin.

nosis after interventional treatment $[12,13]$. We hypothesized that bound thrombin in the thrombus plays an important role in the development of restenosis. This idea was supported by our previous comparative RT-PCR data demonstrating that bound thrombin enhanced the phenotype conversion of VSM cells towards a synthetic type by upregulating SMemb and PAI-1 mRNA expressions [17]. In the present study, bound thrombin upregulation of SMemb and PAI-1 mRNA expressions was further evidenced by Northern blot analysis (fig. 3). However, the mechanism by which bound thrombin upregulated those mRNA expressions remains unknown.

Cell proliferation was not changed by bound thrombin in our study (fig. 5a). Although cell number was not increased by bound thrombin, the incorporation of BrdU tended to be increased by bound thrombin (fig. 5b). These data suggest that bound thrombin simultaneously increases mitogenic activity and apoptosis of VSM cells. It was reported that PAI-1 induced a remarkable increase in apoptosis of human umbilical vein endothelial cells and VSM cells via activation of caspase 3 [23]. Therefore, bound thrombin-induced increase in PAI-1 observed in our study may produce apoptosis of VSM cells.

Migration of VSM cells was regulated by many factors, including platelet-derived growth factor, insulin-like growth factor 1 and basic fibroblast growth factor [24, 25]. Although thrombin is known to induce proliferation of VSM cells, the effect of thrombin on migration of VSM cells is less known. Our data demonstrated that bound thrombin promoted migration activity of the cultured VSM cells, which were abolished by knockdown of SMemb gene expression by ORF-2/pSilencer (fig. 6). The effect of knockdown of SMemb gene expression on migration activity induced by other stimulants (for example, platelet-derived growth factor-BB) was not measured to test if the inhibitory effect of SMemb knockdown on cell migration was specific to that induced by bound thrombin. Because the basal migration activity was inhibited by SMemb knockdown, the inhibitory effect of SMemb knockdown on the cell migration is not likely specific to that induced by bound thrombin. Since bound thrombin is composed of $\alpha$-thrombin and N-terminal regions of the $\alpha$ - and $\gamma$-chains of fibrinogen, bound thrombin can activate the thrombin receptor (protease-activated receptor-1) or bind to integrin $\alpha_{V} \beta_{3}$ on the membrane of VSM cells [26]. Protease-activated receptor 1 activation was reported to lead to $\left[\mathrm{Ca}^{2+}\right]_{\mathrm{i}}$ mobilization, thereby promoting cell migration activity [25]. Alternatively, binding of bound thrombin to $\alpha_{V} \beta_{3}$ of VSM cells upregulated matrix metalloprotease- 2 expression, thereby promoting cell migration activity [27]. In addition, since PAI-1 has been shown to be a potent regulator of vascular cell migration in vitro [28], bound thrombin may promote cell migration activity through upregulation of PAI-1.

In summary, of the $3 \mathrm{SMemb}$ siRNA expression vectors, ORF-2/pSilencer exerted the strongest inhibition on SMemb mRNA expression. Bound thrombin significantly increased SMemb mRNA expression and migration of VSM cells, and these actions were abolished by knockdown of SMemb gene expression by ORF-2/pSilencer. Thus, SMemb gene expression could be necessary for bound thrombin-stimulated migration of VSM cells. Since bound thrombin might be involved in the development of restenosis after angioplasty, ORF-2/pSilencer could be used to inhibit the SMemb gene and suppress the migration of VSM cells, thereby preventing restenosis. 


\section{References}

- Kastrati A, Schomig A, Elezi S, Dirschinger J, Mehilli J, Schuhlen H, Blasini R, Neumann FJ: Prognostic value of the modified American College of Cardiology/American Heart Association stenosis morphology classification for long-term angiographic and clinical outcome after coronary stent placement. Circulation 1999;100:1285-1290.

-2 Radke PW, Klues HG, Haager PK, Hoffmann R, Kastrau F, Reffelmann T, Janssens U, vom Dahl J, Hanrath P: Mechanisms of acute lumen gain and recurrent restenosis after rotational atherectomy of diffuse in-stent restenosis: a quantitative angiographic and intravascular ultrasound study. J Am Coll Cardiol 1999;34:33-39.

- 3 Schofer J, Rau T, Schluter M, Mathey DG: Short-term results and intermediate-term follow-up of laser wire recanalization of chronic coronary artery occlusions: a singlecenter experience. J Am Coll Cardiol 1997; 30:1722-1728.

4 Kuro-o M, Nagai R, Nakahara K, Katoh H, Tsai RC, Tsuchimochi H, Yazaki Y, Ohkubo A, Takaku F: cDNA cloning of a myosin heavy chain isoform in embryonic smooth muscle and its expression during vascular development and in arteriosclerosis. J Biol Chem 1991;266:3768-3773.

5 Francis CW, Markham RE Jr, Barlow GH, Florack TM, Dobrzynski DM, Marder VJ: Thrombin activity of fibrin thrombi and soluble plasmic derivatives. J Lab Clin Med 1983;102:220-230.

-6 Oltrona L, Eisenberg PR, Lasala JM, Sewall DJ, Shelton ME, Winters KJ: Association of heparin-resistant thrombin activity with acute ischemic complications of coronary interventions. Circulation 1996;94:20642071.

7 Reganon E, Ferrando F, Vila V, Villa P, Martinez-Sales V, Fayos L, Ruano M, Aznar J: Increase in thrombin generation after coronary thrombolysis with rt-PA or streptokinase with simultaneous heparin versus heparin alone. Haemostasis 1998;28:99105.

-8 Becker DL, Fredenburgh JC, Stafford AR, Weitz JI: Molecular basis for the resistance of fibrin-bound thrombin to inactivation by heparin/serpin complexes. Adv Exp Med Biol 1997;425:55-66.
$\$ 9$ Weitz JI, Leslie B, Hudoba M: Thrombin binds to soluble fibrin degradation products where it is protected from inhibition by heparin-antithrombin but susceptible to inactivation by antithrombin-independent inhibitors. Circulation 1998;97:544-552.

-10 Eisenberg PR, Siegel JE, Abendschein DR, Miletich JP: Importance of factor Xa in determining the procoagulant activity of whole-blood clots. J Clin Invest 1993;91: 1877-1883.

11 Weitz JI, Hudoba M, Massel D, Maraganore J, Hirsh J: Clot-bound thrombin is protected from inhibition by heparin-antithrombin III but is susceptible to inactivation by antithrombin III-independent inhibitors. J Clin Invest 1990;86:385-391.

12 Ip JH, Fuster V, Israel D, Badimon L, Badimon J, Chesebro JH: The role of platelets, thrombin and hyperplasia in restenosis after coronary angioplasty. J Am Coll Cardiol 1991; 17:77B-88B

13 Moons AH, Levi M, Peters RJ: Tissue factor and coronary artery disease. Cardiovasc Res 2002;53:313-325.

14 Kinjoh K, Nakamura M, Sunagawa M, Kosugi T: Isolation of bound thrombin consisting of thrombin and fibrin N-terminal fragments from clot lysate. Haematologia (Budap) 2002;32:457-465.

15 Kinjoh K, Nakamura M, Zeng G, Sunagawa M, Eguchi Y, Kosugi T: Bound thrombin from crushed clots was composed of athrombin and $\mathrm{N}$-terminal regions of a and $\mathrm{g}$ chains of fibrinogen. Pathophysiol Haemost Thromb 2002;32:165-173.

16 Zeng G, Kinjoh K, Nakamura M, Kosugi T: The activity of postclotting thrombins on platelet activation was identical to that of native thrombin. J Jap Coll Angiol 2002;42:2531.

17 Shimada S, Sunagawa M, Nakamura M, Kosugi $\mathrm{T}$ : Bound thrombin-induced upregulation of myosin heavy chain isoform, SMemb messenger RNA expression in cultured rabbit vascular smooth muscle cells. Int J Tissue React 2003;25:137-148.

18 Shimada S, Sunagawa M, Hanashiro K, Nakamura M, Kosugi T: RNA interference targeting embryonic myosin heavy chain isoform inhibited mRNA expressions of phenotype markers in rabbit cultured vascular smooth muscle cells. Heart Vessels 2007; 22:41-47.
19 Yoshinaga M, Sunagawa M, Shimada S, Nakamura M, Murayama S, Kosugi T: Argatroban, specific thrombin inhibitor, induced phenotype change of cultured rabbit vascular smooth muscle cells. Eur J Pharmacol 2003;461:9-17.

20 Nakamura M, Kinjoh K, Hanashiro K, Tokeshi Y, Sunagawa M, Kosugi T: The bound-thrombin was uncompetitivey inhibited by argatroban. Br J Haematol 1998;102: 138-139.

21 Nakamura M, Sunagawa M, Kosugi T, Sperelakis N: Actin filament disruption inhibits L-type $\mathrm{Ca}^{2+}$ channel current in cultured vascular smooth muscle cells. Am J Physiol Cell Physiol 2000;279:C480-C487.

22 Rovner AS, Thompson MM, Murphy RA: Two different heavy chains are found in smooth muscle myosin. Am J Physiol 1986; 250:C861-C870

23 Al-Fakhri N, Chavakis T, Schmidt-Woll T, Huang B, Cherian SM, Bobryshev YV, Lord RS, Katz N, Preissner KT: Induction of apoptosis in vascular cells by plasminogen activator inhibitor-1 and high molecular weight kininogen correlates with their anti-adhesive properties. Biol Chem 2003;384:423435 .

24 Bornfeldt KE, Raines EW, Nakano T, Graves LM, Krebs EG, Ross R: Insulin-like growth factor-I and platelet-derived growth factor$\mathrm{BB}$ induce directed migration of human arterial smooth muscle cells via signaling pathways that are distinct from those of proliferation. J Clin Invest 1994;93:1266-1274.

25 Pauly RR, Bilato C, Sollott SJ, Monticone R, Kelly PT, Lakatta EG, Crow MT: Role of calcium/calmodulin-dependent protein kinase II in the regulation of vascular smooth muscle cell migration. Circulation 1995;91:11071115.

26 Hynes RO: Integrins: versatility, modulation, and signaling in cell adhesion. Cell 1992;69:11-25

27 Katsuda S, Okada Y: Vascular smooth muscle cell migration and extracellular matrix. J Atheroscler Thromb 1994;1(suppl 1):S34S38.

28 Stefansson S, McMahon GA, Petitclerc E, Lawrence DA: Plasminogen activator inhibitor-1 in tumor growth, angiogenesis and vascular remodeling. Curr Pharm Des 2003;9: 1545-1564. 